\title{
EFFECTS OF ABANDONMENT ON THE FUNCTIONAL COMPOSITION AND FORAGE NUTRITIVE VALUE OF A NORTH ADRIATIC DRY GRASSLAND COMMUNITY (ĆIĆARIJA, CROATIA)
}

\author{
Vitasović Kosić, I ${ }^{1}$ - TARdella, F. M. ${ }^{2}$ - GrbeŠA, D. ${ }^{3}$ - ŠKVORC, Ž. ${ }^{4}$-CATORCI, A. ${ }^{2}$ \\ ${ }^{1}$ University of Zagreb, Faculty of Agriculture, Department of Agricultural Botany, \\ Svetošimunska 25, 10000 Zagreb, Croatia \\ (phone: +385-1-239-3808; fax: +385-1-231-5300) \\ ${ }^{2}$ University of Camerino, School of Environmental Sciences, \\ Via Pontoni 5, I-62032 Camerino (MC), Italy; \\ (phone: +39-0737-404-511; fax: +39-0737-404-508) \\ ${ }^{3}$ University of Zagreb, Faculty of Agriculture, Department of Animal nutrition, \\ Svetošimunska 25, 10000 Zagreb, Croatia \\ (phone: +385-1-239-3800; fax: +385-1-231-5300)
}

${ }^{4}$ University of Zagreb, Faculty of Forestry, Department of Forest Genetics, Dendrology and Botany,

Svetošimunska 25, 10000 Zagreb, Croatia

(phone: +385-1-6666-102; fax: +385-1-6666-113)

*Corresponding author

e-mail: ivitasovic@agr.hr

(Received $14^{\text {th }}$ Sept 2013; accepted $22^{\text {th }}$ Dec 2013)

\begin{abstract}
Carici humilis-Centaureetum rupestris association is one of the most widespread types of pasture in Istria and of great environmental and economic interest. The research aims were to test if forage quantity, nutritive value and functional composition (grasses and grass-like, legumes, and forbs percentage) of these pastures change significantly in relation to: time of the growing season, management type (low use intensity grazing/grazing abandonment) and topographic variables. During 2008, phytomass samples were collected in grazed and ungrazed pastures of Ćićarija (Croatia), in May, June, and September. Their composition in dry matter, ash, crude protein (CP), neutral and acid detergent fiber (NDF, ADF), acid detergent lignin (ADL) and in-vitro dry matter digestibility (IVDMD) were determined and net energy for lactation (NEL) and yield NEL were calculated. These variables followed a double trend, linked to the phenological phases of grasslands and to a land use/topographic gradient. Yield, yield NEL, dry matter, NDF, ADF and ADL increased during the growing season, while CP, NEL and IVDMD decreased. Yield, yield NEL, grasses and forbs, ash, and IVDMD were tied to the ungrazed pastures spread on the slopes, while ADF, ADL and dry matter had stronger correlation with grazed grasslands spread on the flat lands.
\end{abstract}

Keywords: Carici humilis-Centauretum rupestris Horvat 1931, Brachypodium rupestre, productivity, functional groups, forage quality.

\section{Introduction}

Throughout Europe, owing to their low agricultural productivity (Willems, 1990; van Dijk, 1991), semi-natural calcareous grasslands are in strong decline in extension and threatened by abandonment (Luick, 1998; Zervas, 1998; Dullinger et al., 2003; Sebastià et al., 2008; Penksza et al. 2010, 2013; Házi et al. 2011, 2012; Szentes et al., 2011; 
Zimmermann et al., 2011, Kiss et al., 2011). This trend has been also observed in the North Adriatic pastures (Kaligarič et al., 2006) and on the Ćićarija mountainous plateau (Vitasović Kosić, 2011; Vitasović Kosić et al., 2011), where the low intensity use or the abandonment of grassland management practices led to the triggering of vegetation dynamic processes and to a consequent change in floristic, coenological and functional composition (Vitasović Kosić et al., 2012). Indeed, the variability of species assemblage in semi-natural grasslands depends on environmental factors (Belesky et al., 2002a; Catorci et al., 2012b, Zimmerrmann et al., 2011,Szentes et al., 2009a, 2009b, 2012) and on grazing management and history (Holechek et al., 1995; Belesky et al., 2002b). These interacting factors create a mosaic of plant communities, which results in variations in palatability and nutritive value for grazing ruminants (Roukos et al., 2011). For instance, the decrease in herbage use due to pasture abandonment or improper management causes the spread of taller and less digestible vegetation (Louault et al., 2002).

The ability of a grassland to sustain animal growth depends on its phytomass production and herbage nutritive value (Synman, 2002). Hence, the determination of forage quality is important for both nutritional and economic reasons (Rotar et al., 2010). The nutritive value of forage depends on its chemical composition (dry matter; crude ash, crude protein; fraction of fibers, i.e. neutral detergent fiber and, acid detergent fiber; acid detergent lignin; net energy for lactation; in-vitro dry matter digestibility), and is influenced by several factors, including climatic conditions, soil, land form, floristic and functional composition (e.g., the proportion of grasses to legumes), selective ability of grazing animals, stage of maturity of plants when harvested, and forage preservation methods (Sheaffer et al., 1990; Van Soest, 1994; Buxton, 1996; Pérez-Corona et al., 1998; Tallowin and Jefferson, 1999; Vásquez de Aldana et al., 2000; Bruinenberg et al. 2002; Arzani et al., 2006; Dale et al., 2013).

The species composition of a pasture influences animal products, particularly milk and cheese produced in the Mediterranean environments (Licitra et al., 1997). Feed values from several types of Mediterranean pastures were investigated throughout the Mediterranean countries (Tsiovaras et al., 1993; Zervas et al., 1996; Licitra et al., 1997: Ammar et al., 1999, 2004; Skapetas et al., 2004). However, there is no previous report about the forage nutritive value of Ćićarija grasslands and, more specifically, of grasslands referred to as the Carici humilis-Centaureetum rupestris Horvat 1931 association, which is one of the most widespread types of pasture in the Istrian Peninsula (Poldini, 1989), and thus of great potential interest, not only for its biodiversity (Ćićarija grasslands were proposed as Special Protection Area of Natura 2000 network as an important site for habitat $62 \mathrm{~A} 0$ and bird species conservation), but also from an economic viewpoint.

Our hypothesis was that the changes in management of pastures underlie variations in quantity and nutritive value (chemical composition and in-vitro digestibility) of forage. More specifically, our aims were to test if these variables: i) change significantly during the growing season; ii) show significant variations between low intensity use and abandoned pastures; iii) are affected by topographic variables (altitude, aspect, slope angle, and land form). 


\section{Material and methods}

\section{Study area}

The study area (about 1000 ha) is located at the north of the Istrian Peninsula, on the Ćićarija mountainous plateau $\left(45^{\circ} 29^{\prime} 56^{\prime},-45^{\circ} 30^{\prime} 00^{\prime}, \mathrm{N}, 13^{\circ} 59^{\prime} 54^{\prime},-14^{\circ} 00^{\prime}\right.$ $29^{\prime}$ 'E), ranging from 550 to $650 \mathrm{~m}$ a.s.1.

The climate is transitional between Mediterranean and continental pre-Alpine, with cool, rainy winters and long, dry summer periods (Poldini, 1989). Precipitation is about $1400 \mathrm{~mm} / \mathrm{yr}$, most of which falls in autumn; a less pronounced secondary peak occurs as spring turns to summer. From a bioclimatic viewpoint, the study area belongs to the submediterranean belt (Kaligarič, 1997) and the epimediterranean zone of the mediterranean-mountain vegetation belt (Čarni, 2003).

The bedrock consists of limestone; soils are generally brown, shallow and clast-rich.

Pastures, formerly grazed by 160000 sheep, are for the most part undergrazed because of low density of grazers (nowadays there are less than 200 sheep, few cattle heads and horses) or completely abandoned, while meadows are not regularly mown or, in some cases, originate from seeded meadows.

The pastoral landscape is characterized by pastures and meadows, referred to as Scorzonero villosae-Chrysopogonetalia grylli Horvatić \& Horvat in Horvatić 1963 order (Festuco-Brometea Br.-Bl. \& Tx. ex Br.-Bl. 1949 class) and Arrhenatheretalia elatioris Tüxen 1931 order (Molinio-Arrhenatheretea Tüxen 1937 class), respectively.

\section{Experimental design and data collection}

Within homogeneous macro-environmental conditions (submediterranean bioclimatic belt and limestone bedrock), we selected two localities characterised by different land use histories: Slum pastures (hereafter named "Pasture 1", $550 \mathrm{~m}$ a.s.l) subjected to low intensity use (0.5-1 sheep per ha) referred to as the Carici humilisCentaureetum rupestris association, and Vodice pastures (hereafter named "Pasture 2"; $650 \mathrm{~m}$ a.s.1.) abandoned since 30-40 years ago, referred to as the Brachypodium rupestre variant of the above-mentioned association.

During the 2008 growing season, samples of phytomass (fresh green matter) were mown with the quadrat method (Whalley and Hardy, 2000) in five 1 x $1 \mathrm{~m}$ fenced plots, placed, about every $100 \mathrm{~m}$, along a transect in each locality, three times, i.e. in spring (May, $26^{\text {th }}-27^{\text {th }}$; up to early May it snowed), summer (June $23^{\text {rd }}-24^{\text {th }}$, optimum of vegetation), and autumn (September, $22^{\text {nd }}-23^{\text {rd }}$, after the summer drought period). During dormancy of vegetation (winter period) samples were not collected. Sampling was done by cutting all herbaceous vegetation at $5 \mathrm{~cm}$ above soil level, and immediately manually separated into the botanical functional groups: grasses and grass-like species (incl. Poaceae, Cyperaceae and Juncaceae), legumes (Fabaceae) and forbs (all other dicotyledonous families) and weighed. Then the grassland samples, placed in individual paper bags and transported to the laboratory, were dried for $48 \mathrm{~h}$ in a $50{ }^{\circ} \mathrm{C}$ oven, ground with a Cyclotec 1093 mill (FOSS Tecator, Höganäs, Sweden), through a $1 \mathrm{~mm}$ sieve and stored until further analysis.

\section{Analytical methods}

Each sample was analysed with regard to: aboveground fresh phytomass $\left(\mathrm{g} / \mathrm{m}^{2}\right)$ of fresh matter; forage chemical composition in dry matter $(\mathrm{g} / \mathrm{kg} \mathrm{DM})$; crude ash, crude 
protein (CP), neutral detergent fiber (NDF), acid detergent fiber (ADF), acid detergent lignin (ADL); in-vitro dry matter digestibility (IVDMD).

The percentage contribution in terms of grasses and grass-like species, legumes and forbs to the total fresh matter $\left(\mathrm{g} / \mathrm{m}^{2}\right)$ and productivity was calculated.

The $\mathrm{N}$ content of each sample was determined using a Kjeltec 2200 digestion unit (Foss Tecator, Häganäs, Sweden), using AOAC (1990) method. NDF, ADF and ADL were determined using a Fibertec System 2021 Fiber Cap (Foss Tecator, Höganäs, Sweden) according to methods of Van Soest et al. (1991), and ash was determined as the gravimetric residue after heating to $550{ }^{\circ} \mathrm{C}$ for $4 \mathrm{~h}$, according to AOAC (1990) method. IVDMD was measured according to Holden (1999) using an ANKOM Daisy ${ }^{\text {II }}$ Incubator (ANKOM Technology Coorporation, Macedon, NY, USA). Rumen fluid was obtained from two Istrian sheep (slaughtered at sales for meat) fed with forage from the study area. Net energy for lactation (NEL) and yield NEL were calculated according to NRC (2013).

\section{Statistical analysis}

We assessed distribution normality and variance homogeneity of data using the Kolmogorov-Smirnov and Levene tests, respectively. We performed ANOVA and ttests when data met the assumptions required for parametric tests and Kruskal-Wallis and Mann-Whitney U-tests when data did not, to understand which variables were significantly different $(p<0.05)$ between the two relevé groups (low intensity use pastures and abandoned pastures) at each time (spring, summer, and autumn) and among times inside each group. In the latter case pairwise comparisons (t-tests and Mann-Whitney U-tests) between times were run when ANOVA or Kruskal-Wallis test, respectively, detected significant differences $(p<0.05)$ among times; the Holm correction for multiple comparisons was used to avoid Type I error.

To identify the main gradients of variation, the relations among the collected data on yield, botanical functional groups (fresh matter) and forage feed value (response variables), and between response variables and explanatory variables, we performed Canonical redundancy analysis (RDA) of the "plots-by-response variables" matrix, constrained by the type of management (abandoned and low use intensity pasture), the time of growing season (May, June, and September), altitude, slope angle, slope aspect, and land form (flat land, slope with concavity). Prior to RDA, the response variable data were standardized.

We used the STATISTICA software (Statsoft Inc. 2005) to perform the statistical tests, and R, version 2.15.0. (R Core Team, 2012), and vegan R-package, version 2.0-4, to perform RDA.

\section{Results}

\section{Productivity of Carici humilis-Centaureetum rupestris}

Content of dry matter, phytomass yield and yield net energy for lactation (NEL) of pastures referred to as Carici humilis-Centaureetum rupestris are presented in Table 1. The results indicate that dry matter of forage increased from spring to autumn; significant differences $(p<0.05)$ were recorded: at each time between grazed and ungrazed pastures, and in both the land use types between September and the other phases of the growing season. Abandoned pastures had higher average yield and yield 
NEL. Yield peaked in June in both types of management, but differences were significant only in autumn. Yield NEL did not show significant differences between the two types of land use in any considered phase of the growing season.

Table 1. Average dry matter content (DM), green mass yield and yield net energy for lactation (yield NEL) \pm Standard deviation in May, June and September in the pastures of Carici humilis-Centaureetum rupestris association with different types of management (P1: Slum, low use intensity pasture P2: Vodice, abandoned pasture). Significance values from ANOVA or Kruskal-Wallis test (p) (comparisons among times during the growing season in each locality) and from t-test or Mann-Whitney U-test ( $p_{\text {may, june, sept }}$ (comparisons between localities at each time) are indicated. Values within the same column with the same superscripts do not differ significantly.

\begin{tabular}{cllll}
\hline Locality & \multicolumn{1}{c}{ Season } & \multicolumn{1}{c}{ DM $(\mathbf{g} / \mathbf{k g})$} & \multicolumn{1}{c}{ Yield $\left(\mathbf{g} / \mathbf{m}^{2}\right)$} & $\begin{array}{c}\text { Yield NEL } \\
(\mathbf{G J} / \mathbf{h a})\end{array}$ \\
\hline \multirow{4}{*}{ P1 } & May & $386.4^{\mathrm{a}} \pm 23.24$ & $403.6^{\mathrm{a}} \pm 31.71$ & $6.11^{\mathrm{a}} \pm 0.50$ \\
& June & $435.4^{\mathrm{a}} \pm 21.83$ & $573.8^{\mathrm{b}} \pm 97.25$ & $8.79^{\mathrm{a}} \pm 1.87$ \\
& September & $604.92^{\mathrm{b}} \pm 55.67$ & $410.0^{\mathrm{a}} \pm 101.25$ & $8.55^{\mathrm{a}} \pm 2.37$ \\
& Average & $475.57 \pm 101.80$ & $462.47 \pm 112.10$ & $7.82 \pm 2.06$ \\
& $p$ & $<0.001$ & 0.011 & 0.003 \\
\hline \multirow{4}{*}{ P2 } & May & $339.26^{\mathrm{a}} \pm 19.49$ & $407.0^{\mathrm{a}} \pm 59.15$ & $5.81^{\mathrm{a}} \pm 0.98$ \\
& June & $348.36^{\mathrm{a}} \pm 17.27$ & $685.6^{\mathrm{b}} \pm 191.10$ & $9.77^{\mathrm{b}} \pm 2.81$ \\
& September & $517.42^{\mathrm{b}} \pm 22.59$ & $606.0^{\mathrm{ab}} \pm 55.65$ & $10.53^{\mathrm{b}} \pm 0.83$ \\
& Average & $401.68 \pm 86.78$ & $566.20 \pm 164.40$ & $8.70 \pm 2.71$ \\
& $p$ & 0.001 & 0.021 & 0.003 \\
\hline \multirow{3}{*}{ P1 vs. P2 } & $p_{\text {may }}$ & 0.008 & 0.913 & 0.5580 \\
& $p_{\text {june }}$ & $<0.001$ & 0.229 & 0.4260 \\
& $p_{\text {sept }}$ & 0.017 & 0.005 & 0.1170 \\
\hline
\end{tabular}

\section{Proportion of grasslands botanical functional groups}

The contribution of functional groups varied in the two types of management (Fig. 1). During the growing season, in the grazed pastures (P1) average mass fraction of grass and grass-like plants slightly increased, forbs slightly decreased, and legumes remained substantially unchanged. In the abandoned pastures (P2) between summer and autumn the sudden decrease of forbs group caused high increase of grass and grass-like group.

The two pastures did not show significant differences in the amount of legumes and forbs fresh matter during the whole growing season. The share of grass/grass-like plants and forbs diverged significantly $(p<0.01)$ in September $($ Fig. 1$)$.

\section{Relation among phytomass production, forage nutritive value and environmental variables}

The first axis of RDA, performed using altitude, aspect, slope angle, land form, type of land use and time of the growing season as explanatory variables, explained the $51.9 \%$ of the constrained variance and was linked to the time of the growing season; The second axis explained the $27.0 \%$ of the variance and was mainly linked to a land use gradient (Fig. 2) which, in turn, was correlated to topographic factors (particularly altitude). More specifically, abandoned pastures were positively correlated to higher 
altitudes, greater slope angles and southerly aspects (negative values), while grazed pastures were positively correlated with flat lands.
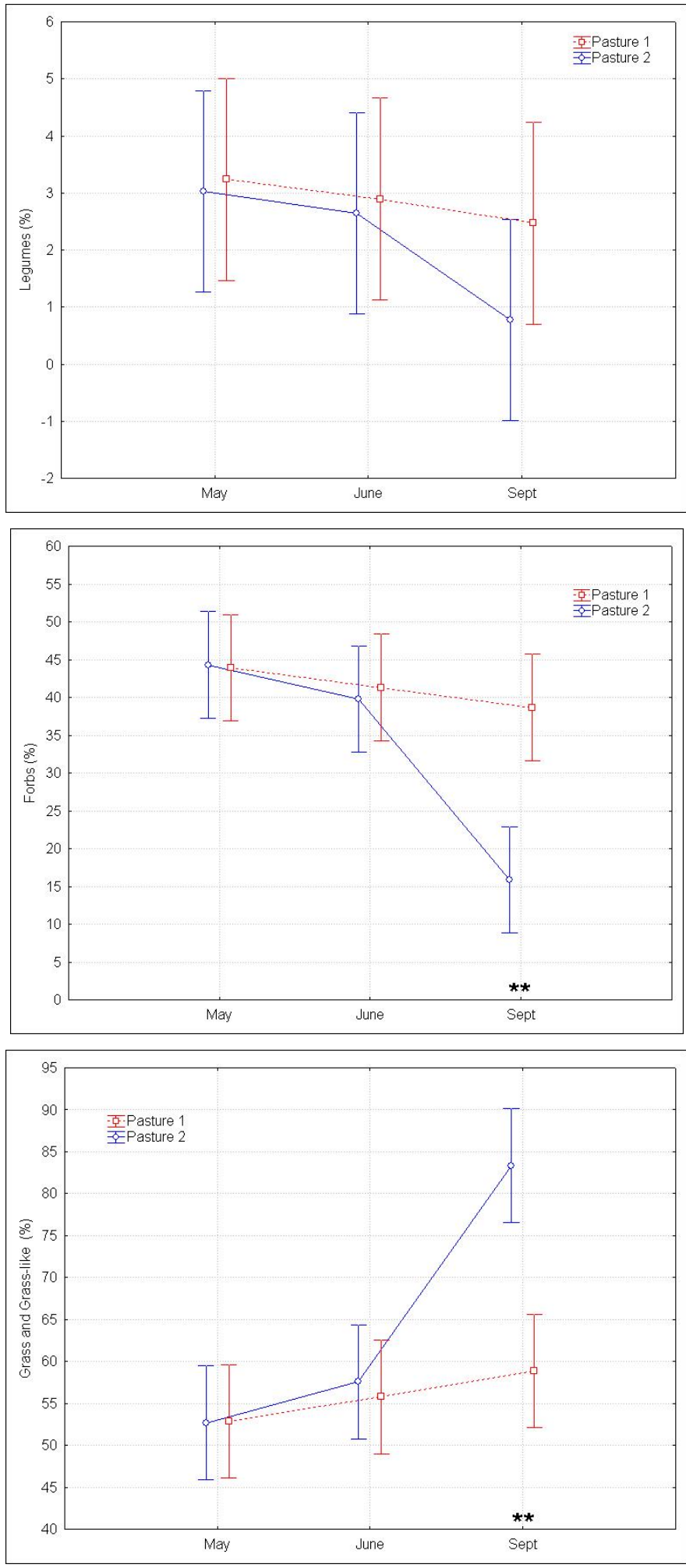

Figure 1. Trends of the average percent values in fresh matter of botanical functional groups (legumes, forbs, grass and grass-like species) in the North Adriatic pastures referred to the Carici humilis-Centaureetum rupestris association. Bars indicate Standard deviation (Pasture 1: Slum, low use intensity pasture; Pasture 2: Vodice, abandoned pasture; $\left.{ }^{* *} p<0.01\right)$. 
Yield, dry matter and the variables linked to forage feed value, followed a double trend, linked to the phenological phases of grasslands and to the land use/topographic gradient: higher yield, yield NEL, DM, ADF and ADL were related to the second half of the growing season, while greater CP, NEL and IVDMD to the first phenological phases. Yield, yield NEL, ash and IVDMD were tied to the ungrazed pastures spread on the slopes, while ADF, ADL and DM had stronger correlation with grazed grasslands of flat lands. DM, NDF, ADF, and ADL were negatively correlated to $\mathrm{CP}$ content, NEL and IVDMD. The greater amount of grasses/grass-like plants and forbs (fresh matter) was found in abandoned pastures.

\section{Forage nutritive value of North Adriatic pastures}

The pastures of the study area have an average low CP content $(90.39 \mathrm{~g} / \mathrm{kg} \mathrm{DM})$ and a high content of fiber fractions: NDF (601.34 g/ kg DM), ADF (368.87 g/kg DM), low IVDMD (49.52\%), and low NEL (4.57 MJ/kg). CP content ranges from 62.62 to $129.08 \mathrm{~g} / \mathrm{kg}$ DM, NDF from 557.87 to $674.24 \mathrm{~g} / \mathrm{kg}$ DM, IVDMD from 459.26 to 536.78 $\mathrm{g} / \mathrm{kg} \mathrm{DM}$, and NEL from 4.1 to $5.4 \mathrm{MJ} / \mathrm{kg} \mathrm{DM}$.

In May, grazed and ungrazed pastures differed significantly in CP (greater in P2) and ADF (greater in P1). In June additional differences were recorded also in ash content and in IVDMD (both greater in P2), while the only significant difference in September was highlighted for ash (Table 2).

Table 2. Average values \pm Standard deviation of crude ash (Ash), crude protein $(C P)$, neutral detergent fiber (NDF), acid detergent fiber (ADF), acid detergent lignin (ADL) content, net energy for lactation (NEL), and in-vitro dry matter digestibility (IVDMD), measured during the growing season in the pastures of Carici humilis-Centaureetum rupestris association with different types of management (P1: Slum, low use intensity pasture; P2: Vodice, abandoned pasture). Significance values from ANOVA or KruskalWallis test ( $p$ ) (comparisons among times during the growing season in each locality) and from t-test or Mann-Whitney U-test ( $p_{\text {may, june, sept) }}$ (comparisons between localities at each time) are indicated. Values within the same column with the same superscripts do not differ significantly between times in each locality. Pairwise comparisons were not performed when ANOVA or Kruskal-Wallis test did not highlight significant differences ( $p \geq 0.05$ ).

\begin{tabular}{|c|c|c|c|c|c|c|c|c|}
\hline Loc & eason & $\begin{array}{r}\text { Ash } \\
(\mathrm{g} / \mathrm{kg} \text { DM) }\end{array}$ & $\begin{array}{r}C P \\
(\mathrm{~g} / \mathrm{kg} D M)\end{array}$ & $\begin{array}{r}\text { NDF } \\
(\mathrm{g} / \mathrm{kg} \text { DM) }\end{array}$ & $\begin{array}{r}\text { ADF } \\
(\mathrm{g} / \mathrm{kg} \text { DM) }\end{array}$ & $\begin{array}{r}\text { ADL } \\
(\mathrm{g} / \mathrm{kg} \mathrm{DM})\end{array}$ & $\begin{array}{r}\mathrm{NEL} \\
(\mathrm{MJ} / \mathrm{kg})\end{array}$ & $\begin{array}{r}\text { IVDMD } \\
\text { (g/kg DM) }\end{array}$ \\
\hline & May & $55.34 \pm 7.86$ & $102.08^{\mathrm{a}} \pm 9.28$ & $596.02 \pm 31.88$ & $378.24 \pm 19.00$ & $86.18^{\mathrm{ab}} \pm 31.96$ & $4.65 \pm 0.81$ & $514.24 \pm 51.28$ \\
\hline & June & $50.71 \pm 3.19$ & $81.03^{\mathrm{b}} \pm 6.76$ & $600.97 \pm 51.57$ & $392.01 \pm 20.44$ & $79.13^{\mathrm{a}} \pm 12.78$ & $4.81 \pm 0.34$ & $467.08 \pm 21.98$ \\
\hline & Sept. & $46.61 \pm 4.12$ & $62.62^{\mathrm{c}} \pm 3.53$ & $576.08 \pm 77.25$ & $381.44 \pm 28.93$ & $116.20^{\mathrm{bc}} \pm 16.26$ & $4.10 \pm 0.55$ & $459.96 \pm 31.06$ \\
\hline & Aver. & $50.89 \pm 6.25$ & $81.90 \pm 17.88$ & $591.02 \pm 53.66$ & $383.90 \pm 22.33$ & $93.84 \pm 26.29$ & $4.52 \pm 0.64$ & $480.43 \pm 42.27$ \\
\hline \multirow[t]{5}{*}{$\mathrm{P} 1$} & $p$ & 0.141 & $<0.001$ & 0.953 & 0.629 & 0.045 & 0.141 & 0.077 \\
\hline & May & $54.31^{\mathrm{a}} \pm 3.20$ & $129.08^{\mathrm{a}} \pm 4.12$ & $557.87^{\mathrm{a}} \pm 38.97$ & $328.84^{\mathrm{a}} \pm 13.44$ & $62.93 \pm 21.00$ & $5.39^{\mathrm{a}} \pm 0.39$ & $536.78^{\mathrm{a}} \pm 35.71$ \\
\hline & June & $66.16^{\mathrm{ab}} \pm 8.71$ & $102.45^{\mathrm{b}} \pm 5.05$ & $602.84^{\mathrm{ab}} \pm 38.70$ & $362.94^{\mathrm{b}} \pm 7.88$ & $70.48 \pm 11.15$ & $4.85^{\mathrm{ab}} \pm 0.36$ & $534.12^{\mathrm{a}} \pm 32.26$ \\
\hline & Sept. & $70.79^{b} \pm 8.61$ & $65.12^{\mathrm{c}} \pm 1.75$ & $674.24^{\mathrm{b}} \pm 58.57$ & $369.75^{\mathrm{b}} \pm 10.34$ & $108.94 \pm 49.09$ & $3.63^{\mathrm{b}} \pm 1.07$ & $459.26^{\mathrm{b}} \pm 23.89$ \\
\hline & Aver. & $63.75 \pm 9.87$ & $98.88 \pm 27.39$ & $611.65 \pm 65.59$ & $353.84 \pm 21.05$ & $80.79 \pm 35.85$ & $4.63 \pm 1.00$ & $510.05 \pm 46.99$ \\
\hline \multirow[t]{3}{*}{$\mathrm{P} 2$} & $p$ & 0.011 & $<0.001$ & 0.006 & $<0.001$ & 0.122 & 0.005 & 0.003 \\
\hline & $p_{\text {may }}$ & 0.840 & $<0.001$ & 0.129 & 0.001 & 0.211 & 0.225 & 0.443 \\
\hline & $p_{\text {june }}$ & 0.006 & $<0.001$ & 0.841 & 0.018 & 0.287 & 0.855 & 0.005 \\
\hline P1 vs. P2 & $p_{\text {sept }}$ & $<0.001$ & 0.193 & 0.053 & 0.411 & 0.762 & 0.406 & 0.969 \\
\hline
\end{tabular}


Figure 2. Redundancy analysis ordination graph for yield, forage feed value variables and botanical functional groups, using altitude, aspect, slope angle, land form (conc - slightly concave slope; flat - flat land), management type (grazing - low intensity use pasture; grazing aband.: abandoned pasture), and time (May, June, and September) as constraining variables. Numbers indicate sites (DM - dry matter; ash - crude ash; CP - crude protein; NDF - neutral detergent fiber; $A D F$ - acid detergent fiber; $A D L$ - acid detergent lignin; NEL - net energy for lactation; IVDMD - in-vitro dry matter digestibility).

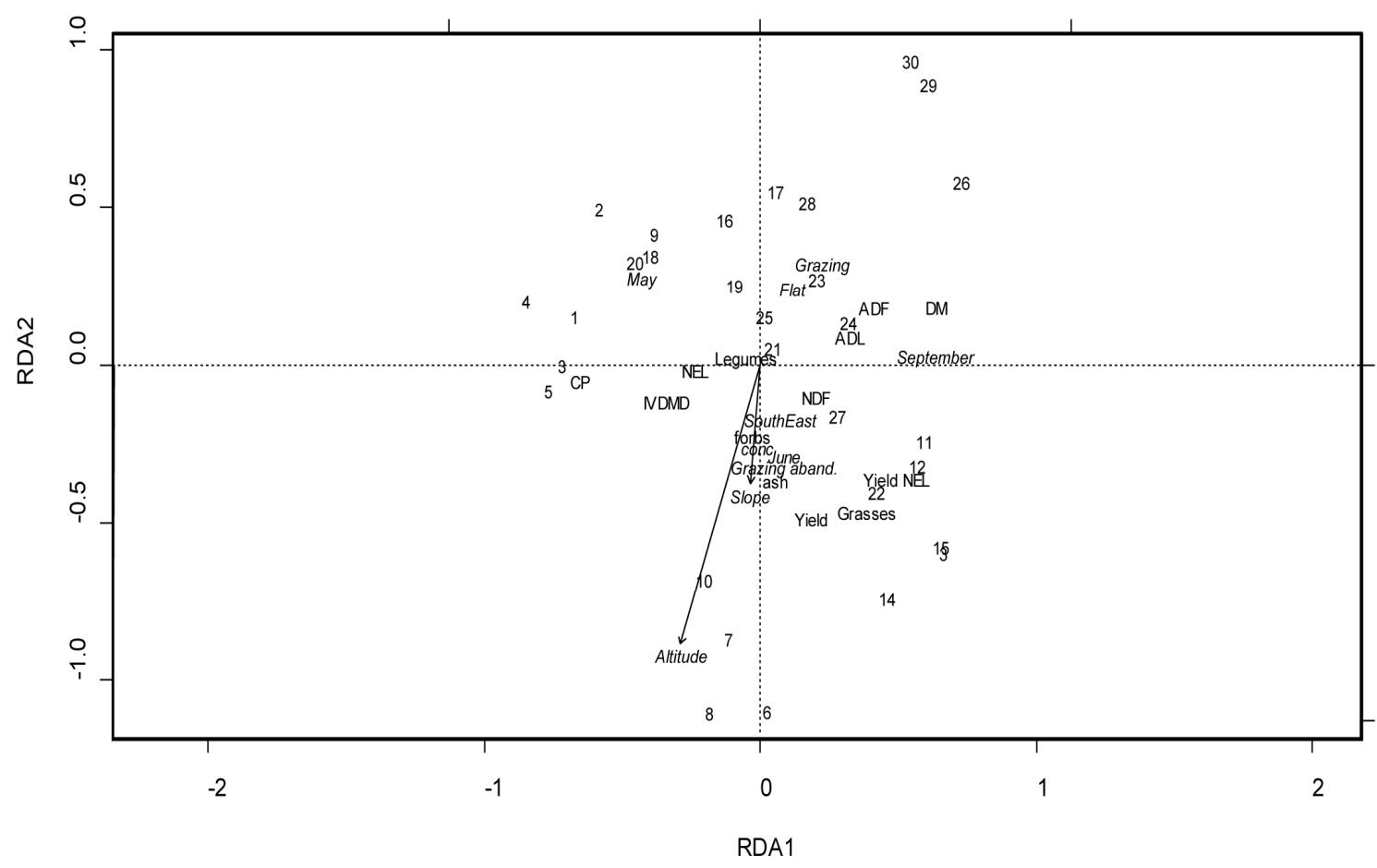

\section{Discussion}

The research outcomes highlighted that the variables which define the quantity and quality of forage, follow a main gradient related to the phenology of the grassland community. In fact, we observed a general trend during the growing season, characterised by the increase in dry matter, fiber (NDF and ADF) and lignin (ADL) content, and the decrease in NEL, IVDMD and CP. Thus, pastures provide more digestible and high quality value forage in spring, when plants are still young. The forage quality declined during the growing season because of the increase in fibers and lignin content, which is responsible for the relative increase in dry matter, and reducing the energy available per mass unit. The increase in fiber is in accordance with Pérez Corona et al. (1994) and Heitschmidt et al. (1995) who related the stage of maturity of plants and age of tissue to the NDF content, which increases in older tissue. We detected also a significant decrease in crude protein content from May to September. This is consistent with Kirby et al. (1989) and Vázquez de Aldana et al. (2000) who observed that the crude protein content declines with stage of maturation. Considering that $6-8 \%$ of crude protein is considered as a threshold, below which either the intake or digestibility of forage falls off, and animal maintenance requirements are not met (Milford and Minson, 1965; Tamminga et al., 1979; Nocek and Russell, 1988), pastures 
of the study area have not good nutritional value (6-6.5\% of crude protein) only at the end of the growing season.

The obtained results confirm also that the dry matter content is a good indicator of nutritional value, which agrees with Miraglia et al. (2008) who stated that the higher dry matter content is indicator of lower crude protein and higher share of lignin in seminatural pastures.

The RDA highlighted a second gradient linked to land use. More specifically, abandonment of North Adriatic grasslands is related to the higher altitudes and steeper south-east-facing slopes, while grazing, although with low intensity, persists on flat lands. A similar spatial trend of abandonment was recorded also in the Apennine ridge (Bracchetti et al., 2012; Catorci et al., 2012a).

The ungrazed pastures analysed were particularly related to grasses and grass-like plants. This observation is consistent with the results of previous research carried out in North Adriatic grasslands which highlighted a species change in the community, due to the triggering of dynamic successional processes as a consequence of management abandonment (Vitasović Kosić et al., 2011). In particular, it was acknowledged that this change was caused mainly by the spread of Brachypodium rupestre, a competitive stress-tolerant graminoid which quickly spreads by means of rhizomes (Grime et al., 1988) and tends to form extensive patches (Catorci et al., 2013a). The invasion of Brachypodium species in abandoned grasslands is widely documented throughout Europe (e.g. Buckland et al., 2001; Bonanomi and Allegrezza, 2004), where it is causing threat to biodiversity (During and Willems, 1984; Bobbink and Willems, 1987; Wilson et al., 1995; Bonanomi et al., 2006, 2009; Catorci et al., 2011), and was recorded in the North Adriatic pastures as well (Vitasović Kosić et al., 2012). The affirmation of grasses (including also other graminoids such as Bromus erectus Huds., Festuca sp. pl., and Koeleria sp. pl.) with tolerance strategies and erect leaves in the abandoned condition is consistent with the findings of some authors (e.g. Skarpe, 2001; Pykälä, 2004; Catorci et al., 2013b) who argued that exclusion of grazers causes the increase in abundance of plants with erect leaves to the detriment of prostrate species.

It is known that abandonment may change the main parameters affecting the forage quantity/quality (Pavlů et al., 2006). In fact, in the study case, yield differed between grazed and ungrazed pastures (average values of 4.62 and $5.66 \mathrm{~g} / \mathrm{m}^{2}$, respectively), diverging significantly in the later stage of the growing season (Table 1). The results indicate that in ungrazed pastures, yield and yield NEL increased significantly from May to June, when Brachypodium rupestre is in full growth, reaching its peak in phytomass and the optimal period for reproduction before the summer drought period. This may account for the greater phytomass values of ungrazed pastures than in grazed ones. Indeed in the study area, the cover of Brachypodium rupestre may be greater than 50\% (Vitasović Kosić et al., 2012). Moreover, in more productive undisturbed grasslands species do not allocate resources to produce antiherbivore defence structures, but devote them to new photosynthetic tissue (Coley et al., 1985). This may account for the lower fiber and lignin content, and the related higher values of IVDMD, recorded in abandoned pastures.

The higher forage digestibility and CP content may be substantially ascribed to the forb and legume functional groups; instead grass and grass-like species are more related to fibers and lignin content (Fig. 2). Indeed, it is known that most of the non-grass species have lower fiber content than the grasses and are highly digestible (Mojo et al., 
1993), and leguminous plants have a higher nutritional value than grass species (Peeters and Janssens, 1998).

Also forbs showed a greater amount of fresh matter in summer (Fig. 2). This is consistent with Ramirez and Nunez-Gonzalez (2006), who observed that relatively high proportion of forbs in summer helps to maintain nutrients, moisture and yield of grasslands during the summer drought, contributing to maintain the stability of nutritive value of semi natural grassland throughout the growing season.

Moreover, the abandoned condition and the amount of grass, was mainly linked to south-east facing slopes. This is in accordance with Peco et al. (2012) and Catorci et al. (2013b) who argued that, in the most stressing submediterranean habitats such as southerly aspects, which experience a summer drought stress period, the spread of grasses is promoted by the absence of herbivory.

Grazing is positively related to lignin and fiber content and negatively related to NEL, yield, yield NEL, and IVDMD. Indeed plants respond to herbivory reducing the probability and severity of grazing by changing tissue chemistry, growth rate, morphology and resource allocation (Belsky, 1986; Bryant et al., 1992; Rooke and Bergström, 2007), producing toxic secondary metabolites and involving mechanical defences like spines, tough leaves and protective coatings (Alba et al. 2011, Vitasović Kosić et al., 2011).

\section{Conclusions}

Pastures of Ćićarija are very valuable for their high potential production, their good nutritional value (especially for the spring protein content and digestibility), and their high plant diversity; therefore, special attention should be paid to their protection and conservation through management measures, such as maintaining a general low pressure of grazing by means of grazing rotation, to prevent the process of secondary succession and the spread of unpalatable competitive tall grasses at a landscape level.

As factors which affect plant diversity affect yield and nutritive value of grassland as well (White, 1983), knowing the phytomass production and the forage nutrient content of pastures is the first step in predicting the minimum number of herbivores required to maintain the optimal plant diversity of Ćićarija.

The results of this research could allow the draft of the guidelines for a comprehensive and optimal management of grasslands, not only in the study area, but also in other submediterranean areas where Carici humilis-Centauretum rupestris association spreads. This can contribute to the improvement of the sheep production and its high-value products (milk, meat and cheese) and, at the meantime, to the preservation of the diversity of flora and grassland vegetation in Croatia and Europe.

Acknowledgements: Results shown in this paper arise from the research project (Project number 1781780469-2276), carried out by the support of The Ministry of Science, Education and Sports of The Republic of Croatia.

\section{REFERENCES}

[1] Alba, J.M., Glas, J.J., Schimmel, B.C.J., Kant, M.R. (2011): Avoidance and suppression of plant defenses by herbivores and pathogens. - Journal of Plant Interactions 6: 221-227. 
[2] Ammar, H., López, S., Bochi, O., García, R., Ranilla, M. J. (1999): Composition and in vitro digestibility of leaves and stems of grasses and legumes harvested from permanent mountain meadows at different maturity stages. - Journal of Animal Feed Science 8: 599610.

[3] Ammar, H., López, S., Gonzàlez, J. S., Ranilla, M. J. (2004): Seasonal variations in the chemical composition and in vitro digestability of some Spanish leguminous shrub species. - Animal Feed Science and Technology 115: 327-340.

[4] AOAC - Association of Official Analytical Chemists (1990): Official Methods of Analysis. $15^{\text {th }}$ ed. - AOAC. Arlington. VI.

[5] Arzani, H., Basiri, M., Khatibi, F., Ghorbani, G. (2006): Nutritive value of some Zagros Mountain rangeland species. - Small Ruminant Research 65: 128-135.

[6] Belesky, D. P., Fedders, J. M., Ruckle, J. M., Turner K. E. (2002a): Bermudagrass-white clover-bluegrass sward production and botanical dynamics. - Agronomy Journal 94: 575-584.

[7] Belesky, D. P., Feldhake, C. M., Boyer D. (2002b): Herbage production and botanical composition of hill pasture as a function of clipping and site features. - Agronomy Journal 94: 351-358.

[8] Belsky, A. J. (1986): Does herbivory benefit plants? A review of the evidence. - The American Naturalist 127: 870-892.

[9] Bobbink, R., Willems, J. H. (1987): Increasing dominance of Brachypodium. pinnatum (L.) Beauv. in chalk grasslands: a threat to a species-rich ecosystem. - Biological Conservation 40: 301-314.

[10] Bonanomi, G., Allegrezza, M. (2004): Effetti della colonizzazione di Brachypodium rupestre (Host) Roemer et Schultes sulla diversità di alcune fitocenosi erbacee dell'Appennino centrale [Effects of colonization of Brachypodium rupestre (Host) Roemer et Schultes on the diversity of some herbaceous plant communities of the central Apennine]. - Fitosociologia 41(2): 51-69.

[11] Bonanomi, G., Caporaso, S., Allegrezza, M. (2006): Short-term effects of nitrogen enrichment, litter removal and cutting on Mediterranean grassland. - Acta Oecologica 30: 419-425.

[12] Bonanomi, G., Caporaso, S., Allegrezza, M. (2009): Effects of nitrogen enrichment, plant litter removal and cutting on a species-rich Mediterranean calcareous grassland. - Plant Biosystems 143: 443-455.

[13] Bracchetti, L., Carotenuto, L., Catorci, A. (2012): Land-cover changes in a remote area of central Apennines (Italy) and management directions. - Landscape and Urban Planning 104: 157-170.

[14] Bruinenberg, M. H., Valk, H., Korevaar, H., Struik, P. C. (2002): Factors affecting digestibility of forages from semi-natural grasslands. - Grass and Forage Science 57: 292-301.

[15] Bryant, J. P., Reichardt, P. B., Clausen, T. P. (1992): Chemically mediated interactions between woody plants and browsing mammals. - Journal of Range Management 45: 1824.

[16] Buckland, S.M., Thompson, K., Hodgson, J.G., Grime, J.P. (2001): Grassland invasions: effects of manipulations of climate and management. - Journal of Applied Ecology 38: 289-294.

[17] Buxton, D.R. (1996): Quality-related characteristics of forages as influenced by plant environment and agronomic factors. - Animal Feed Science and Technology 59: 37-49.

[18] Čarni, A. (2003): Vegetation of forest edges in the central part of Istria (Istria, northwestern Croatia). - Natura Croatica 12 (3): 131-140.

[19] Catorci, A., Antolini, E., Tardella, F.M., Scocco, P. (2013a): Assessment of interaction between sheep and poorly palatable grass: a key tool for grassland management and restoration. - Journal of Plant Interactions, doi:10.1080/17429145.2013.776706. 
[20] Catorci, A., Cesaretti, S., Gatti, R. (2013b): Effect of long-term abandonment and spring grazing on floristic and functional composition of dry grasslands in a central Apennine farmland. - Polish Journal of Ecology 61(3): 505-518.

[21] Catorci, A., Cesaretti, S., Gatti, R., Ottaviani G. (2011): Abiotic and biotic changes due to spread of Brachypodium genuense (DC.) Roem. \& Schult. in sub-Mediterranean meadows. - Community Ecology 12(1): 117-125.

[22] Catorci, A., Foglia, M., Tardella, F. M., Vitanzi, A., Sparvoli, D., Gatti, R., Galli, P., Paradisi, L. (2012a): Map of changes in landscape naturalness in the Fiastra and Salino catchment basins (central Italy). - Journal of Maps 8(1): 97-106.

[23] Catorci, A., Ottaviani, G., Gatti, R., Vitasović Kosić, I., Cesaretti, S. (2012b): Effect of spatial and temporal patterns of stress and disturbance intensities in a sub-Mediterranean grassland. - Plant Biosystems 146: 352-367.

[24] Coley, P. D., Bryant, J. P., Chapin, F. S. (1985): Resource availability and plant antiherbivore defense. - Science 230: 895-899.

[25] Dale, L. M., Thewis, A., Rotar, I., Boudry, C., Păcurar, F. S., Lecler, B., Agneessens, R., Dardenne, P., Baeten, V. (2013): Fertilization Effects on the Chemical Composition and In vitro Organic Matter Digestibility of Semi-natural Meadows as Predicted by NIR Spectrometry. - Notulae Botanicae Horti Agrobotanici Cluj-Napoca 41(1): 58-64.

[26] Dullinger, S., Dirnböck, T., Grabherr, G. (2003): Patterns of Shrub Invasion into High Mountain Grasslands of the Northern Calcareous Alps, Austria. - Arctic, Antarctic, and Alpine Research 35(4): 434-441.

[27] During, H. J., Willems, J. H. (1984): Diversity models as applied to a chalk grassland. Vegetatio 57: 103-114.

[28] Grime, J. P., Hodgson, J. G., Hunt, R. (1988): Comparative plant ecology: a functional approach to common British species. Hyman, London.

[29] Házi, J., Bartha, S., Szentes, Sz., Wichmann, B., Penksza, K. (2011): Seminatural grassland management by mowing of Calamagrostis epigejos in Hungary. - Plant Biosystems 145: 699-707.

[30] Házi, J., Penksza, K., Bartha, S., Hufnagel, L., Tóth, A., Gyuricza, Cs., Szentes, Sz. (2012): Cut mowing and grazing effects with grey cattle on plant species composition in case of Pannon wet grasslands. - Applied Ecology and Enviromental Research 10: 223231.

[31] Heitschmidt, R. K., Grings, E. E., Haferkamp, M. R., Karl, M. G. (1995): Herbage dynamics on two northern great plains range sites. - Journal of Range Management 48: 211-217.

[32] Holden, L. A. (1999): Comparison of methods of in vitro dry matter digestibility for ten feeds. - Journal of Dairy Science 82: 1791-1794.

[33] Holechek, J. L., Pieper, R. D., Herbel. C. H. (1995): Range management principles and practices. - Prentice Hall, Englewood Cliffs, New Jersey.

[34] Kaligarič M. (1997): Rastlinstvo primorskega krasa in Slovenske Istre - Travniki in pašniki. Zgodovinsko društvo za južno primorsko - Znanstveno raziskovalno središče Republike Slovenije Koper, Koper. [Vegetation of the coastal Karst and Slovenian Istria Meadows and pastures - Historical Society of Southern coast - Science and Research Centre. Slovenia Republic, Koper].

[35] Kaligarič M., Culiberg M., Kramberger B. (2006): Recent vegetation history of the North Adriatic grasslands: expansion and decay of an anthropogenic habitat. - Folia Geobotanica 41: 241-258.

[36] Kirby, D. G., Green, D. M., Mings, S. (1989): Nutrient composition of selected macrophytes in Northern prairie wetlands. - Journal of Range Management 42: 323-326.

[37] Kiss, T., Lévai, P., Ferencz, Á., Szentes, Sz., Hufnagel, L., Nagy, A., Balogh, Á., Pintér, O., Saláta, D., Házi, J., Tóth, A., Wichmann, B., Penksza, K. (2011): Change of composition and diversity of species and grassland management between different 
grazing intensity - in Pannonian dry and wet grasslands. - Applidied Ecology and Environmental Research 9(3): 197-230.

[38] Licitra, G., Carpino, S., Schadt, I., Avondo, M., Barresi, S. (1997): Forage quality of native pastures in a Mediterranean area. - Animal Feed Science and Technology 69: 315328.

[39] Louault, F., Soussana, J. F., Perrodin, M. (2002): Long-term effects of a reduced herbage use in a semi-natural grassland. I. Plant functional traits and plant response groups. - In: Durand, J. L., Emile, J. C., Huyghe, C., Lemaire, G. (eds.) Multi-function grasslands: quality forages, animal products and landscapes. Proceedings of the 19th General Meeting of the European Grassland Federation, La Rochelle, France, 27-30 May 2002 Grassland Science in Europe 7: 338-339.

[40] Luick, R. (1998): Ecological and socio-economic implications of livestock-keeping systems on extensive grasslands in south-western Germany - Journal of Applied Ecology 35: 979-982.

[41] Milford, B. L., Minson, D. J. (1965): Intake of tropical pasture species. - In: Proceedings 9th International Grassland Congress, Sao Paolo, Brazil, 815-822.

[42] Miraglia, N., Costantini, M., Polidori, M., Meineri, G., Peiretti, P.G. (2008): Exploitation of a natural pasture by wild horses: comparison between nutritive characteristics of the land and the nutrient requirements of the herds over a 2-year period. - Animal 2(3): 410418.

[43] Mojo, L., Dekimpe, J., Etievant, P.X., Addeo, F. (1993): The neutral volatile compounds of water buffalo milk. - Italian Journal of Food Science 1: 43-56.

[44] Nocek, J.E., Russell, J.B. (1988): Protein and energy as an integrated system: relationship of ruminal protein and carbohydrate availability to microbial synthesis and milk production. - Journal of Dairy Science 71: 2070-2107.

[45] NRC - National Research Council (2013): Nutrient Requirements of Small Ruminants: Sheep, Goats, Cervids, and New World Camelids. Committee on the Nutrient Requirements of Small Ruminants, Board on Agriculture and Natural Resources, Division on Earth and Life Studies - National Research Council of the National Academies. - The National Academies Press. Washington, DC.

[46] Pavlů, V., Hejcman, M., Pavlů, L., Gaisler, J., Nežerková, P. (2006): Effect of continuous grazing on forage quality, quantity and animal performance. - Agriculture Ecosystems and Environment 113: 349-355.

[47] Peco, B., Carmona, C.P., de Pablos, I., Azcárate, F.M. (2012): Effects of grazing abandonment on functional and taxonomic diversity of Mediterranean grasslands. Agriculture Ecosystems and Environment 152: 27-32.

[48] Peeters, A., Janssens, F. (1998): Species-rich grasslands: diagnostics, restoration and use in intensive livestock production systems. - In: Nagy, G., Peto, K. (eds.): Ecological Aspects of Grassland Management. Proceedings of the 17th General Meeting of the European Grassland Federation, Debrecen Agricultural University, Debrecen, Hungary, May 18-21, pp. 375-393.

[49] Penksza, K., Szentes, S., Loksa, G., Dannhauser, C., Házi, J., (2010): A legeltetés hatása a gyepekre és természetvédelmi vonatkozásai a Tapolcai- és a Káli-medencében. Természetvédelmi Közlemények 16: 25-49.

[50] Penksza, K., Házi, J., Tóth, A., Wichmann, B., Pajor, F., Gyuricza, Cs., Póti, P., Szentes, Sz. (2013): Eltérő hasznosítású szürkemarha legelő szezonális táplálóanyag tartalom alakulás, fajdiverzitás változása és ennek hatása a biomassza mennyiségére és összetételére nedves pannon gyepekben. - Növénytermelés 62(1): 73-94.

[51] Pérez Corona, M. E., García Criado, B., Vázquez de Aldana, B. R., García Ciudad, A. (1994): Effect of topographic and temporal (maturity) gradients on the nutritive quality of semiarid herbaceous communities. - Communications in Soil Science and Plant Analysis 25: 2047-2061. 
[52] Pérez-Corona, M. E., Vázquez de Aldana, B. R., Garcia-Criado, B., Garcia-Ciudad, A. (1998): Variations in nutritional quality and biomass production of semiarid grasslands. Journal of Range Management 51: 570-576.

[53] Poldini, L. (1989): La vegetazione del Carso isontino e triestino. Studio del paesaggio vegetale tra Trieste, Gorizia e i territori adiacenti [The vegetation of the Isonzo and Trieste Karst. Study of plant landscape of Trieste, Gorizia and adjacent territories]. Edizioni Lint Trieste.

[54] Pykälä, J. (2004): Cattle grazing increases plant species richness of most species trait groups in mesic semi-natural grasslands. - Plant Ecology 175: 217-226.

[55] R Core Team (2012): R: A language and environment for statistical computing. - R Foundation for Statistical Computing. Version 2.15.0. Wien, AT. http://www.Rproject.org

[56] Ramirez, R.G., Nunez-Gonzalez, M. (2006): Chemical composition digestion and mineral content of native forbes consumed by range sheep. - Journal of Animal and Veterinary Advances 5(12): 1158-1164.

[57] Rooke, T., Bergström, R. (2007): Growth, chemical responses and herbivory after simulated leaf browsing in Combretum apiculatum. Plant Ecology 189: 201-212.

[58] Rotar, I., Păcurar, F. S., Gârda, N. T., Morea, A. (2010): The management of oligotrophic grasslands and the approach of new improvement methods. - Romanian Journal of Grasslands and Forage Crops 1: 57-70.

[59] Roukos, C., Papanikolaou, K., Karalazos, A., Chatzipanagiotou, A., Mountousis, I., Mygdalia, A. (2011): Changes in nutritional quality of herbage botanical components on a mountain side grassland in North-West Greece. - Animal Feed Science and Technology 169: 24-34.

[60] Sebastià, M.T., de Bello, F., Puig, L., Taull, M. (2008): Grazing as a factor structuring grasslands in the Pyrenees. - Applied Vegetation Science 11: 215-222.

[61] Sheaffer, C.C., Marten, G.C., Rabas, D.L., Martin, N.P., Miller, D.W. (1990): Reed canarigrass. Minnesota Agricultural Experiment Station Bulletin, St. Paul, MN, 5951990.

[62] Skapetas, B., Nitas, D., Karalazos, A., Hatziminaoglou, I. (2004): A study on the herbage mass production and quality for organic grazing sheep in a mountain pasture of northern Greece. - Livestock Production Science 87: 277-281.

[63] Skarpe, C. (2001): Effects of Large Herbivores on Competition and Succession in Natural Savannah Rangelands - In: Tow, P.G., Lazenby, A. (eds.) Competition and succession in pastures, CABI Publishing, Wallingford, pp. 175-192.

[64] Snyman, H. A. (2002): Short-term response of rangeland botanical composition andproductivity to fertilization ( $\mathrm{N}$ and $\mathrm{P}$ ) in a semi-arid climate of South Africa. Journal of Arid Environments 50: 167-183.

[65] StatSoft, Inc. (2005): STATISTICA (data analysis software system), version 7.1. www.statsoft.com

[66] Szentes Sz., Wichmann B., Házi J., Tasi J., Penksza K. (2009a): Vegetáció és gyep produkció havi változása badacsonytördemici szürkemarha legelökön és kaszálón. - Tájökológiai Lapok 7(2): 319-328.1

[67] Szentes, Sz., Tasi, J., Wichmann, B., Penksza, K. (2009b): Botanikai és gyepgazdálkodási vizsgálatok 2008. évi eredményei a badacsonytördemici szürkemarha legelön. - Gyepgazdálkodási Közlemények 7: 73-78.

[68] Szentes, Sz., Dannhauser, C., Coetzee, R., Penksza, K, (2011): Biomass productivity, nutrition content and botanical investigation of Hungarian Grey cattle pasture in Tapolca basin. - AWETH 7(2): 180-198.

[69] Szentes, Sz., Sutyinszki, Zs., Szabó, G., Zimmermann, Z., Házi, J., Wichmann, B., Hufnágel, L., Penksza, K., Bartha, S. (2012): Grazed Pannonian grassland 
beta-diversity changes due to $\mathrm{C}_{4}$ yellow bluestem. - Cent. Eur. J. Biol. 7(6): 10551065

[70] Tallowin, J. R. B., Jefferson, R. G. (1999): Hay production from lowland seminatural grasslands: a review of implications for livestock systems. - Grass and Forage Science 54: 99-115.

[71] Tamminga, S., Van Der Koelen, C.J., Van Vuuren, A.M. (1979): The effect of level of feed intake on nitrogen entering the small intestine of dairy cows. Inst. animal Feeding and Nutrition Research "Hoom" Lelysted, Netherlands. - Livestock Production Science 6(3): 255-262.

[72] Tsiovaras, C. N., Koukoura, Z., Ainalis, A., Platis, P. (1993): Dynamic relationship between long-term sheep grazing and range productivity in a semi-arid grassland. - In: Management of Mediterranean shrubland and related forage resources. 7th Meeting of the FAO European Subnetwork on Mediterranean pastures and Fodder Crops. Mediterranean Agronomic Institute of Chania, April 21-23, Crete, Greece, pp. 151-154.

[73] van Dijk, G. (1991): Half-natuurlijke graslanden in Europa verdwijnen. Natuur en Milieu [Semi-natural grasslands disappear in Europe. Nature and Environment] 15(9): 8-13.

[74] Van Soest, P. J. (1994): Nutritional Ecology of the Ruminant. Second edition. - Cornell University Press, Ithaca and London, USA.

[75] Van Soest, P. J., Robertson, J. B., Lewis, B. A. (1991): Methods for dietary fiber, neutral detergent fiber and nonstarch polysaccharides in relation to animal nutrition. - Journal of Dairy Science 74: 3583-3597.

[76] Vázquez de Aldana, B. R., García Ciudad, A., Pérez Corona, M. E., García Criado, B. (2000): Nutritional quality of semi-arid grassland in western Spain over a 10-year period: changes in chemical composition of grasses, legumes and forbs. - Grass and Forage Science 55: 209-220.

[77] Vitasović Kosić, I. (2011): Grasslands Scorzonero-Chrysopogonetalia order on the Ćićarija: Flora, Vegetation and Feed value. - Dissertation $(\mathrm{PhD})$ in Croatian, University of Zagreb, Faculty of Agriculture.

[78] Vitasović Kosić, I., Tardella, F.M., Catorci, A. (2012): Effect of management modification on coenological composition of the North Adriatic pastoral landscape (Ćićarija, Croatia). - Hacquetia 11(1): 17-46.

[79] Vitasović Kosić, I., Tardella, F.M., Ruščić, M., Catorci, A. (2011): Assessment of floristic diversity, functional composition and management strategy of North Adriatic pastoral landscape (Croatia). - Polish Journal of Ecology 59(4): 765-776.

[80] Whalley, R. D. B., Hardy, M. B. (2000): Measuring Botanical Composition of Grasslands. - In: 't Mannetje, L., Jones, R.M. (eds.) Field and Laboratory Methods for Grassland and Animal Production Research, Oxford University Press, USA.

[81] White, R. G. (1983): Foraging patterns and their multiplier effects on productivity of northern ungulates. - Oikos 40: 377-384.

[82] Willems, J.H. (1990): Calcareous grasslands in Continental Europe - In: Hillier, S.H., Walton, D. W. H., Wells D. A. (eds.): Calcareous grasslands: ecology and management, Bluntisham Books, Bluntingham, UK.

[83] Wilson, E.J., Wells, T.C.E., Sparks, T.H. (1995): Are calcareous grasslands in the UK under threat from nitrogen deposition? An experimental determination of a critical load. Journal of Ecology 83: 823-832.

[84] Zervas, G. (1998): Quantifying and optimizing grazing regimes in Greek mountain systems. - Journal of Applied Ecology 35: 983-986.

[85] Zervas, G., Fegeros, K., Papadopoulos, G. (1996): Feeding system of sheep in a mountainous area of Greece. - Small Ruminant Research 21: 11-17.

[86] Zimmermann, Z., Szabó, G., Bartha, S., Szentes, Sz., Penksza, K. (2011): Juhlegeltetés hatásainak természetvédelmi célú vizsgálata legelt és müvelésből kivont gyepek növényzetére. - AWETH 7(3): 234-262. 